\title{
Paleoseismic Evidence of Characteristic Slip on the Western Segment of the North Anatolian Fault, Turkey
}

\author{
by Y. Klinger,* K. Sieh, E. Altunel, A. Akoglu, A. Barka, T. Dawson, T. Gonzalez, \\ A. Meltzner, and T. Rockwell
}

\begin{abstract}
We have conducted a paleoseismic investigation of serial fault rupture at one site along the 110-km rupture of the North Anatolian fault that produced the $M_{\mathrm{w}} 7.4$ earthquake of 17 August 1999. The benefit of using a recent rupture to compare serial ruptures lies in the fact that the location, magnitude, and slip vector of the most recent event are all very well documented. We wished to determine whether or not the previous few ruptures of the fault were similar to the recent one. We chose a site at a step-over between two major strike-slip traces, where the principal fault is a normal fault. Our two excavations across the 1999 rupture reveal fluvial sands and gravels with two colluvial wedges related to previous earthquakes. Each wedge is about $0.8 \mathrm{~m}$ thick. Considering the processes of collapse and subsequent diffusion that are responsible for the formation of a colluvial wedge, we suggest that the two paleoscarps were similar in height to the 1999 scarp. This similarity supports the concept of characteristic slip, at least for this location along the fault. Accelerator mass spectrometry (AMS) radiocarbon dates of 16 charcoal samples are consistent with the interpretation that these two paleoscarps formed during large historical events in 1509 and 1719. If this is correct, the most recent three ruptures at the site have occurred at 210- and 280-year intervals.
\end{abstract}

\section{Motivation}

Over the past several years, evidence has accumulated in support of the hypothesis that the magnitude of fault slip at a particular site along a fault does not vary greatly from event to event (Sieh, 1996). However, data are still too scant to determine how universal these observations are and under which conditions faults produce similar serial ruptures and under which conditions they do not.

The $M_{\mathrm{w}} 7.4$ Izmit, Turkey, earthquake of 17 August 1999 was produced by more than $100 \mathrm{~km}$ of right-lateral rupture along the North Anatolian fault (Fig. 1). Detailed documentation of the fresh rupture (Armijo et al., 2000; Lettis et al., 2000; Barka et al., 2002; Langridge et al., 2002) combined with a centuries-long historical record of prior large earthquakes (Ambraseys and Finkel, 1995; Ambraseys, 2002) provide an unusual opportunity to investigate the nature of sequential fault rupture. Since prior historical ruptures are known only from records of shaking, paleoseismic work is necessary to characterize the nature and amount of slip from one event to the next.

*Present address: Institut de Physique du Globe, Paris, France.
Tectonic Setting of the North Anatolian Fault and the 1999 Earthquake Sequence

The arcuate, right-lateral North Anatolian fault system forms the northern margin of the Anatolian block, a minor crustal plate that is extruding westward, out of the collision zone between Eurasia and Arabia (Fig. 1). Along its eastern $1000 \mathrm{~km}$, the structure consists primarily of one fault (Barka, 1992). Farther west, the fault system divides into southern, central, and northern strands. The northern branch, part of which broke in 1999, appears to carry most of the long-term slip. From Global Positioning System measurements, the dextral slip rate on the North Anatolian fault has been estimated to be $24 \pm 1 \mathrm{~mm} / \mathrm{yr}$, the rate of motion between the Anatolian block and Eurasian blocks (McClusky et al., 2000). A slip rate of $17 \mathrm{~mm} / \mathrm{yr}$, averaged over the past $5 \mathrm{My}$, has been derived for the northern strand of the fault (Armijo et al., 1999). Thus, the central and southern strands may have a combined rate of about $7 \mathrm{~mm} / \mathrm{yr}$.

During the past 500 years the North Anatolian fault has produced many large, destructive earthquakes. Historical accounts of shaking and damage suggest that most of the fault ruptured in each of two major seismic episodes during the sixteenth and the eighteenth centuries (Ambraseys and Fin- 
kel, 1991, 1995; Ambraseys, 2002). Furthermore, most of the fault system reruptured between 1912 and 1999 (Stein et al., 1997; Ambraseys and Jackson, 2000). Along the northern branch, only the 160-km-long section of the fault beneath the Sea of Marmara has not ruptured in the past century (Barka, 1996, 1999).

The rupture of August 1999 consists of four distinct segments. From east to west, these are the Karadere, Sakarya, Izmit-Sapança, and Gölcük segments (Fig. 2) (e.g., Barka et al., 2002). Each segment is delimited by step-overs or bends. The Izmit-Sapança and Gölcük segments are separated by a right step about $2 \mathrm{~km}$ wide. A northwest-striking, northeast-side-down, normal fault about $3.2 \mathrm{~km}$ long, which we here call the Gölcük fault, is the principal structure that occupies the step-over. Detailed description of the rupture associated with the 1999 Izmit earthquake is beyond the scope of this article, and the reader should refer to the special issue of the Bulletin edited by Toksöz (2002).

\section{Paleoseismic Investigations along the Gölcük Segment}

\section{Trench Site}

The Gölcük fault traverses a large alluvial fan delta built by the northward-flowing Hisar River (Fig. 3), with the Kazikle River contributing to the building of the western side of the fan. This Quaternary fan delta is composed mostly of alluvium derived from the Triassic rocks of the mountain range that bounds the Gulf of Izmit on the south. Along much of the step-over fault, a scarp, clearly delineated in the topography, existed prior to 1999 . The current height of the scarp varies along strike from about 1 to $6 \mathrm{~m}$, with the maximum slip associated to the 1999 Izmit earthquake being located where the cumulative scarp is the highest (Barka et $a l ., 2002)$. Since this is up to 4 times the height of the scarp that formed in 1999, it is reasonable to suspect that the older scarp formed as a result of several prior ruptures.

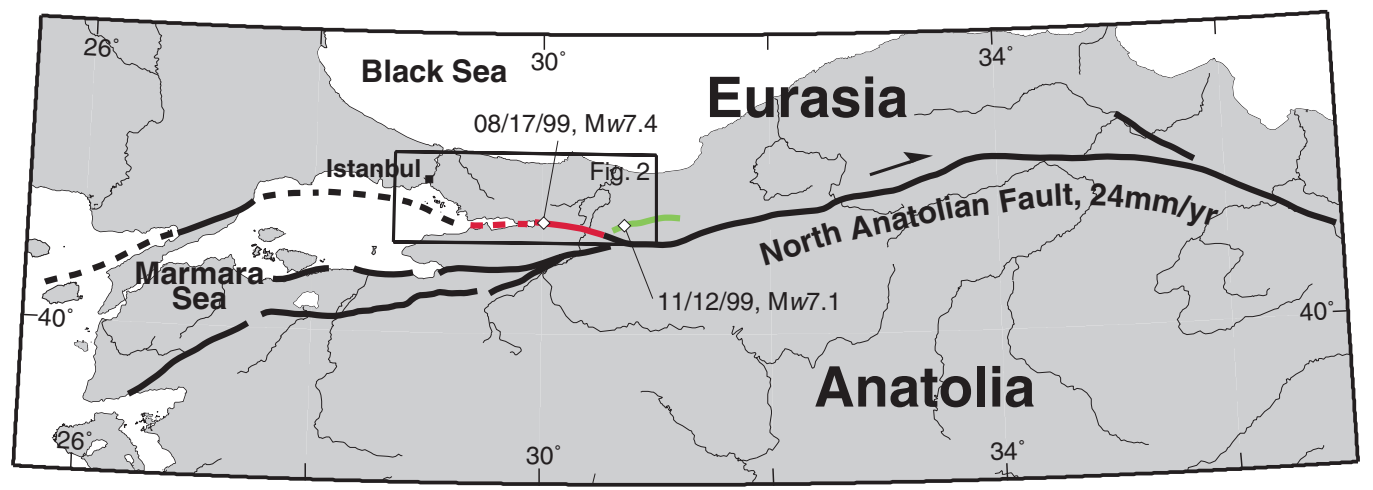

Figure 1. The highly segmented North Anatolian fault has ruptured repeatedly in the past 500 years of historical record. The rupture of several segments in August (red) and November 1999 (green) afforded an unusual opportunity to compare the slip of sequential ruptures.

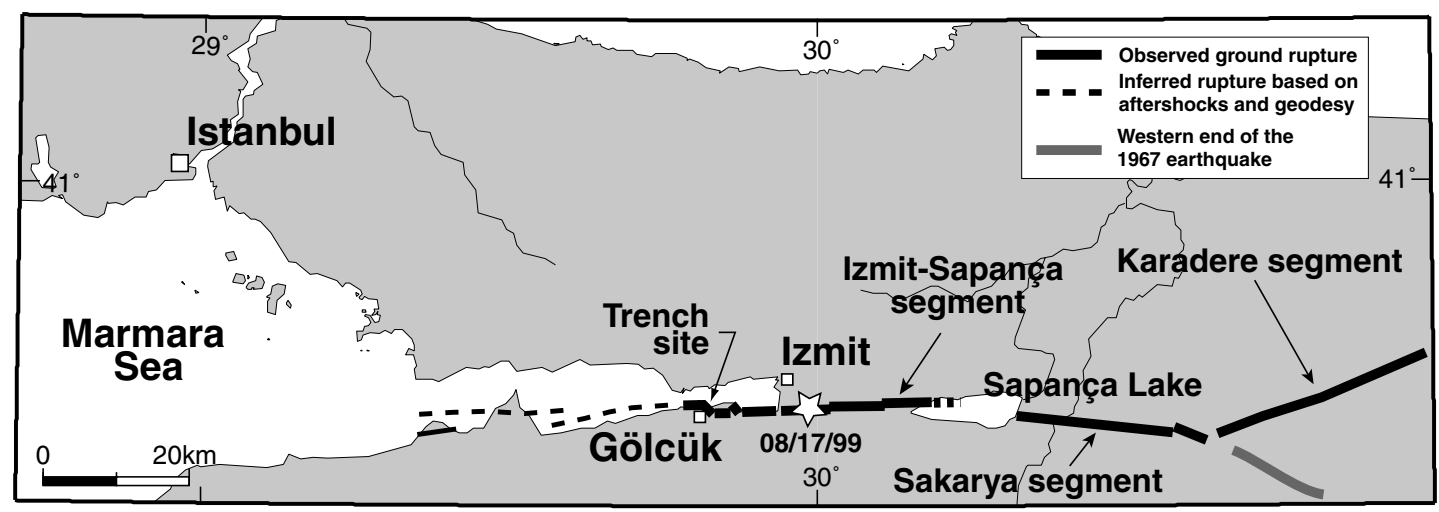

Figure 2. The August 1999 earthquake was caused by rupture of four different segments: the Gölcük segment, the Izmit segment, the Sakarya segment, and the Karadere segment. Right-lateral slip of several meters was predominant along most of the rupture (Barka et al., 2002). Secondary ruptures (lighter lines) with significant vertical slip occurred very locally (Gonzalez et al., 2000; Walls et al., 2001). 


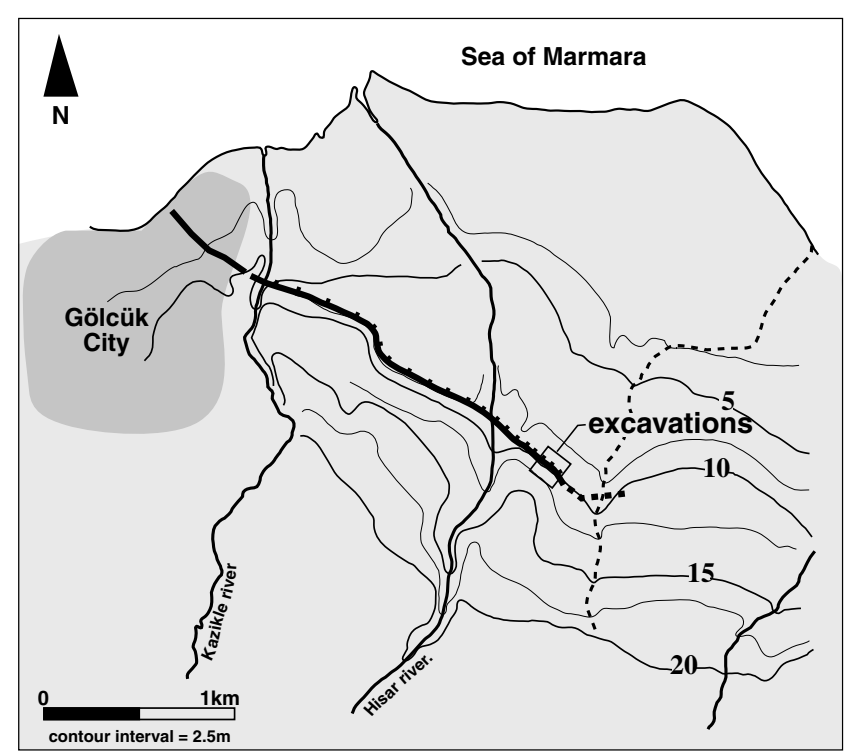

Figure 3. In the vicinity of our paleoseismic site, on the delta of the Hisar River, the Gölcük segment exhibits a 2-km-wide extensional step-over. Our excavations were across the step-over fault, which exhibited more than $1 \mathrm{~m}$ of nearly pure normal slip. The topographic contours show the existence of a preexisting scarp associated with activity prior to 1999.

The Hisar River has incised the part of the fan on the upthrown block south of the fault. The material that has been eroded from the block south of the scarp has been redeposited just north of the scarp, forming a small alluvial fan upon the larger Hisar delta fan (Fig. 3). The shape of the younger fan shows that, in the course of its formation, the river has swept across the entire fan, at times flowing along the fault scarp and depositing sediments at its base.

The entire length of the Gölcük fault was mapped in detail soon after the earthquake (Gonzalez et al., 2000; B. Meyer, et al., personal comm., 2000; Barka et al., 2002). Slip on the Gölcük fault was almost purely normal. Measurable components of right-lateral slip occurred primarily in association with local deviations in strike. The vertical component of slip averaged about $1.5 \mathrm{~m}$, with a maximum value of $2.3 \mathrm{~m}$. The lateral component reached a maximum of about $1 \mathrm{~m}$ but was commonly much less.

\section{The Paleoseismic Site}

Our paleoseismic site is located east of the Hisar River (Fig. 3), where the 1999 rupture is unusually simple. Here the 1999 scarp was $1.6 \mathrm{~m}$ high and nearly uneroded at the time of our excavations. We opened two trenches along the 1999 rupture, the first in November 1999, just after the earthquake. The second was cut in July 2000 to investigate further the relationships seen in the first excavation and to retrieve additional datable material. When the second trench was opened, in July 2000, the scarp had already begun to degrade and collapsing material from the free face had formed an incipient colluvial wedge along parts of the scarp (Fig. 4).

Figure 5a shows the topography of the site, including the pre- and post-1999 scarps and colluvial wedges. Profile AB (Fig. 5b) shows that the total apparent offset across the scarp is about $3.8 \mathrm{~m}$, about $2 \mathrm{~m}$ greater than the height of the 1999 scarp. The actual height of the scarp is somewhat greater, because the profile does not extend across the crest of the scarp.

\section{The Excavations}

The two trenches expose similar faulted late Holocene fluvial and colluvial deposits. We could not inspect the lowest part of each trench, because of high groundwater. Pumping of the groundwater limited flooding of the trench but also encouraged collapse of portions of the walls.

Trench 1. Figure 6 depicts the strata and fault zone that were exposed in trench 1 . This excavation was made in November 1999, 3 months after the earthquake (Gonzalez et al., 2000). At that time, the 1999 scarp had sustained no erosional collapse, as evidenced by the pristine nature of the fault scarp and by the presence of a pre-earthquake grassy mat that continued up to the fault scarp on the down-thrown block. The scarp free face, however, was cut back by about $30 \mathrm{~cm}$ during the excavation.

Other than the 20- to 60-cm-thick organic soil at the ground surface, none of the units exposed in trench 1 appeared on both sides of the fault zone, making the total vertical offset across the fault larger than the thickness of the exposed downstream deposits plus the height of the scarp.

Southwest of the fault, strata on the up-thrown block consist of a sequence of well-sorted planar and lenticular sand and gravel beds overlain by a sequence of finer-grained sandy beds. The contact between the coarser and finer beds (F6/F7) is a shallow eastward-dipping angular unconformity. Beneath the unconformity, the sandy, well-sorted, massive gravels are heterolithologic and clasts are subangular to subrounded (units F7, F9, and F10). Lenses and planar beds of sand below and between the gravel beds are also well sorted, and some exhibit planar lamination or cross-bedding (F8). We interpret the coarser beds to have formed during periods of high stream discharge and the sandy beds to have formed during less energetic flow.

The nature of the younger sandy beds is consistent with deposition in a fluvial overbank setting. These constitute the upper meter or so of the section southwest of the fault (F1F4) and are less well sorted. The finer-grained beds probably formed by settling of suspended load, whereas those with coarser sandy components probably were emplaced as bed load. The youngest bed beneath the modern soil layer, for example, grades upward from medium to coarse sand to clayey, fine to medium sand. This is consistent with initial emplacement as bed load and later deposition as suspended load. 


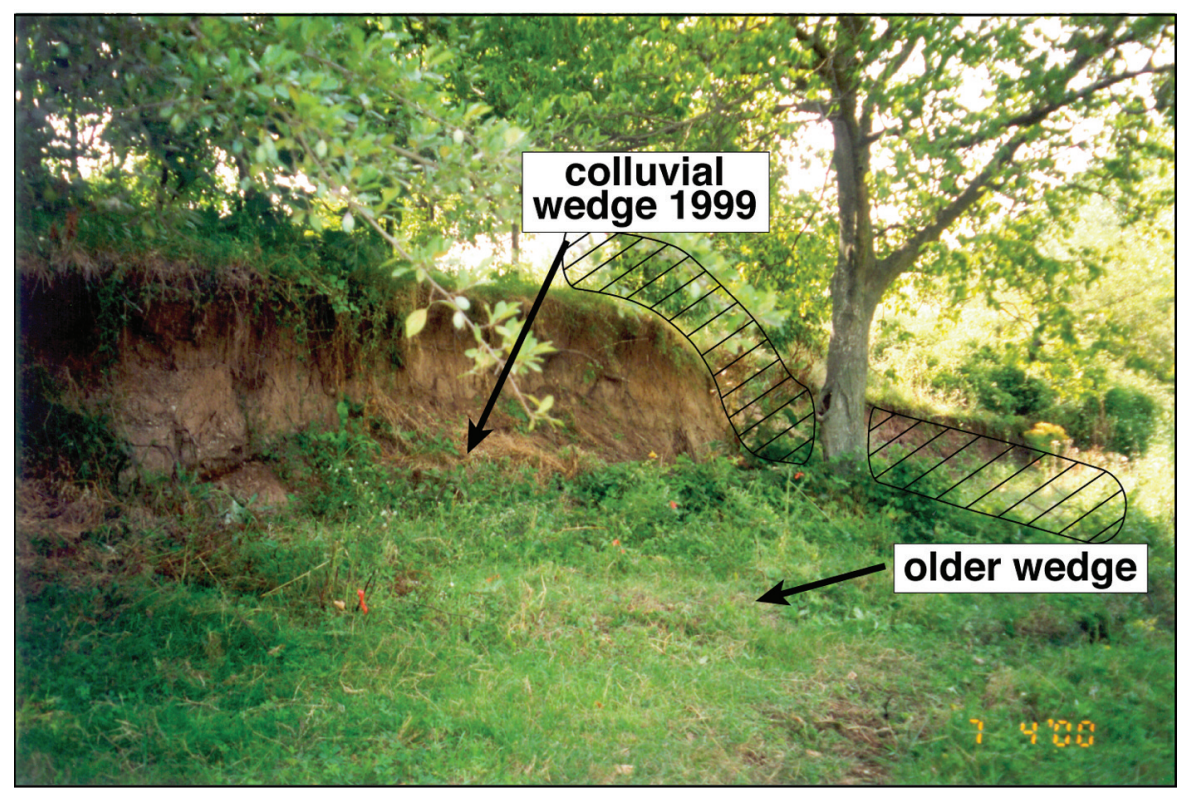

Figure 4. The scarp of the August 1999 rupture was $1.6 \mathrm{~m}$ high at the excavation. Some parts of the scarp had already collapsed to form a colluvial wedge by the time the photo was taken in July 2000. An older colluvial wedge, formed by earlier collapse of previous scarps, appears in the foreground. The hatched band in the background indicates the rough location of trench 1 .

The sediments exposed southwest of the fault appear to have been deposited during the middle of the first millennium A.D. or earlier. Detrital charcoal from a bed about a meter below the ground surface, above the angular unconformity, yielded a calibrated radiocarbon age of A.D. 400600 (Table 1). Tiles found in coarse fluvial channel sediments in a similar position farther below the surface of the up-thrown block, in an excavation, about $900 \mathrm{~m}$ to the northwest, are similar in age to this sample, as they appear to be early Byzantine in age (A.D. 500-600) (Gonzalez et al., 2000).

The lowest unit exposed on the down-thrown block (G0) consists of well-sorted pebbles. Above unit G0 are two poorly sorted triangular beds that thicken toward the fault. These beds, W1 and W2, intercalate with sandy lenses that pinch out toward the fault (L1-L7) (Fig. 6). W1 and W2 appear to be of colluvial origin. Like the gravely deposits across the fault, the rounding and sorting of G0 indicate deposition in a high-energy fluvial environment. Auxiliary pits dug next to the trench showed, however, that this bed forms a narrow deposit that parallels the fault (Gonzalez et al., 2000). This geometry indicates that it formed in a channel that ran parallel to and on the northeast side of the fault, possibly along a pre-existing scarp.

The sequence of deposits that overlie the gravel appears to be colluvial wedges. W1 consists of a block of older sediment, nearest the fault zone (W1a) and overlying debris (W1b). W1a consists of material that is nearly identical in color and composition to sandy clay bed, F6, across the fault and just above the unconformity, draped by a thin gravel lens. The younger portion of the lower wedge, W1b, is massive clayey, silty sand. The color and grains that form this part of the wedge are similar to those in F1-F5 across the fault. Thus, it seems plausible, at first glance, that this part of the wedge formed by progressive, piecemeal erosion of these beds.

Three sandy lenses (L1, L2, and L3) overlie wedge W1. Each of these lenses thins toward the fault scarp and onto the wedge. The lowest lens is composed of silty sand grading upward into silty clay. We interpret this as a suspended-load deposit, formed in a very shallow pool of quiet water on the down-thrown block. L2 consists of massive silty sand to clayey sand. The upper surface of this unit is nearly horizontal, with the distal end sloping gently away from the fault. We interpret L2 to be a suspended-load deposit, but we cannot totally discard the possibility that it is a colluvial deposit, formed by the slow erosion of the fault scarp. L3 consists of massive sandy clay. The upper surface of this deposit is highly irregular, probably due to bioturbation during the years it formed the ground surface. In general, however, the surface slopes away from the fault. The upper few centimeters are darkened by organic material and display slight bioturbation. These characteristics indicate a soil-forming interval before deposition of the overlying units. We infer this deposit to be scarp-derived colluvial wedge. The soil indicates a period of stability following deposition of L3. One sample of detrital charcoal within L2 (Table 1, sample 14C-4) indicates that the younger portions of the wedge (W1b) formed within or somewhat before the range A.D. 1480-1680. This interpretation is reinforced by the dates 
(a)

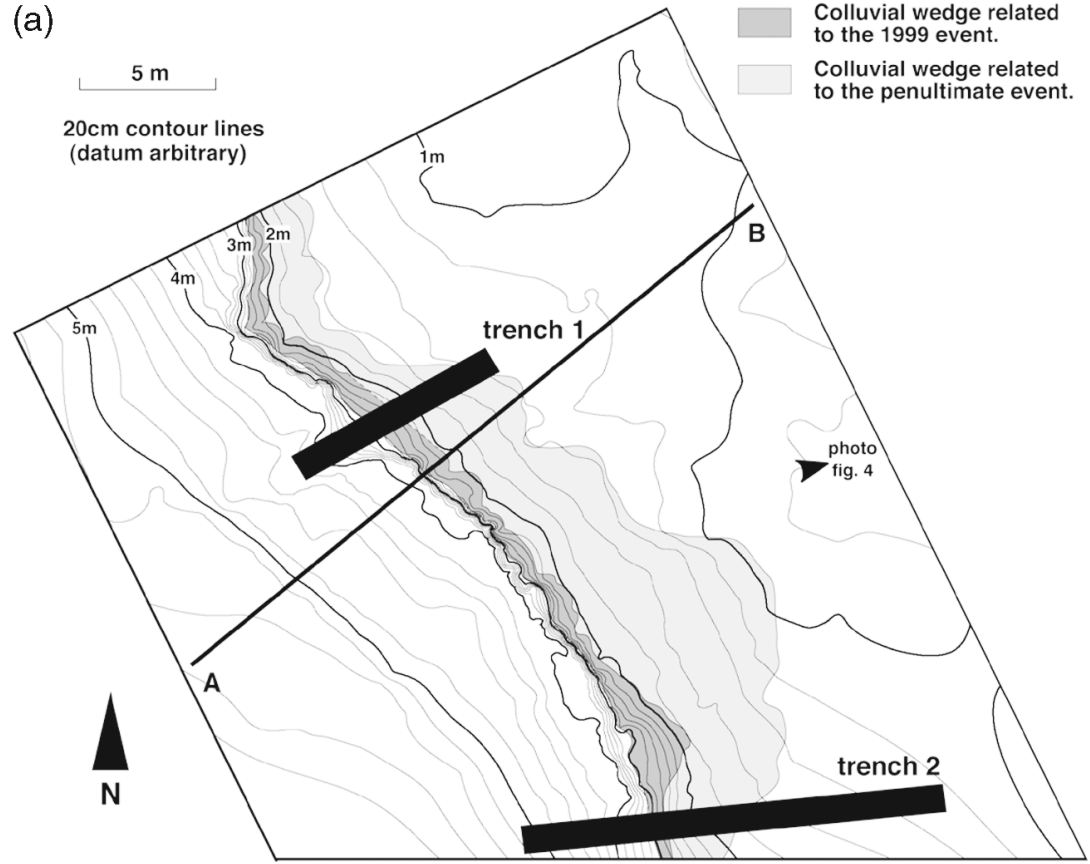

Figure 5. (a) This topographic and geologic map of the site shows the location of the two trenches, the 1999 and older colluvial wedges, and the 1999 and older scarp. The topography was surveyed with a total station (July 2000). (b) A topographic profile across the scarp shows that the apparent cumulative scarp height is about $3.8 \mathrm{~m}$.

(b)

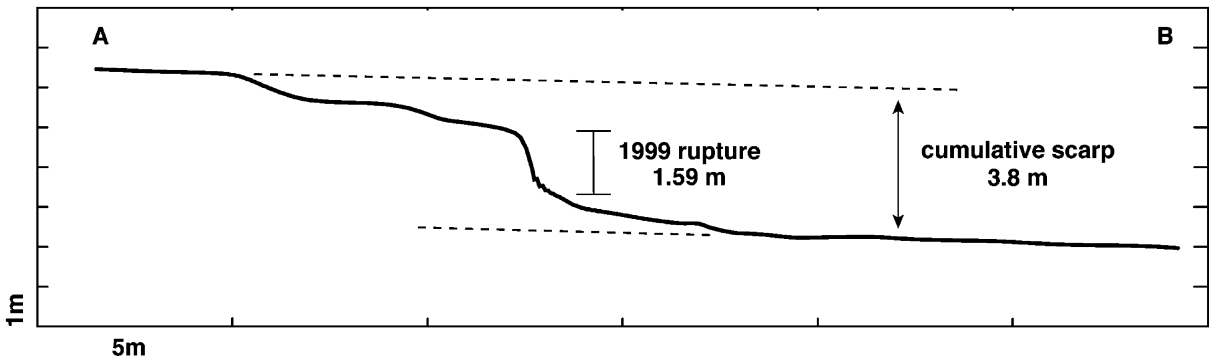

from the units corresponding to $\mathrm{W} 1$ in trench 2 (see next section).

A second sequence of colluvial wedges and lenses overlies L3. Wedge W2 consists of two parts. The lower part (W2a) consists of poorly sorted sand and silt, similar to the exposed nonpebbly portion of the up-thrown block, that is, units F1-F6. The upper part of wedge 2 (W2b) is formed of sandier material. The upper surface of the toe of wedge W2 is slightly darker. This indicates that enough time elapsed between the deposition of wedge 2 and the overlying lenses to allow the formation of a weak organic soil.

Units L4-L7 overlie the toe of wedge W2 and slope away from the fault. Their position, composition, and shape indicate that they are the result of gradual erosion of the scarp, after initial collapse of the scarp to form wedge W2. Units L4 and L5 consist of sandy material that could be derived from the raveling of sandy units of the up-thrown block exposed during faulting. Alternatively, considering the small volume of L4, the lens L4 may have formed by remobilization of material from W2b. Units L6 and L7 consist of pebbly sand, indicating that at least part of these colluvial units must be derived from different units than lenses L4 and L5.
From similarities of facies between some units forming the colluvial wedges and units in the up-thrown block, it is tempting to try to make correlations to constrain the temporal framework for the emplacement of the wedges. For example W1a is similar in composition to F6, and the overlying gravel drape is similar to unit F7. Thus, it might be suggested that W1a is an intact block that fell from F6 and then was mantled by gravels that fell from F7 after these units were exposed by fault slip. We do, in fact, interpret W1a to be a coherent block that fell off the fault scarp, followed by fall of a little gravel, but it cannot have fallen from unit F6. None of the units F1-F7 appear to have suffered any erosion at the scarp face, at least until our backhoe took a chunk out of the scarp. Thus, an origin of block W1a from any of these units is untenable. The base of W1a must be restored to a position at least as high as the current ground surface on the up-thrown block, and the block forming W1a has to come from a unit located above the present ground surface that is no longer present on the up-thrown block. (We will show this reconstruction later.) The source units on the up-thrown block are missing due to erosion, in large part due to intense man-made grading of the surface for agricultural purposes. 


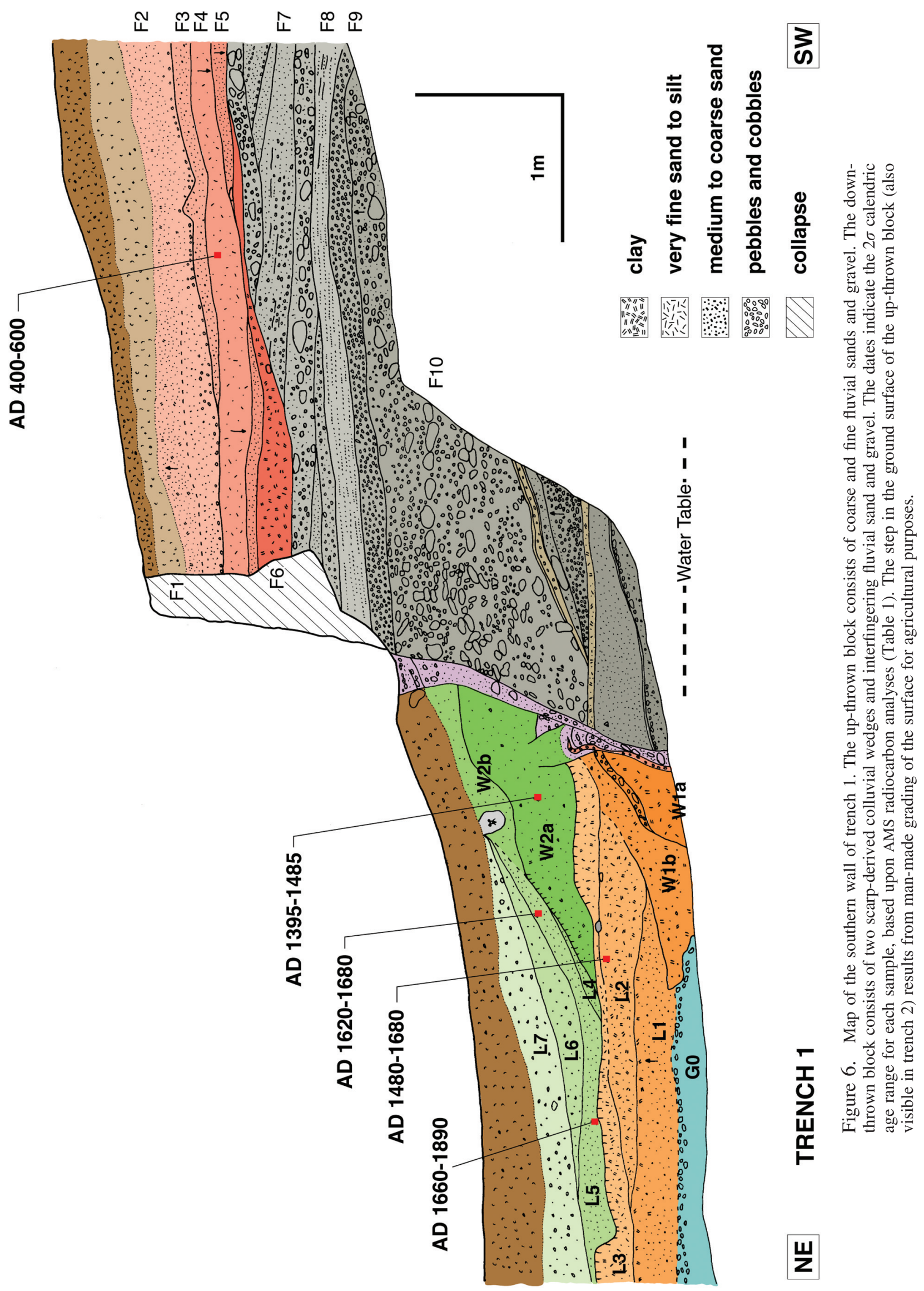


Table 1

Radiocarbon Dates for Trench 1

\begin{tabular}{lccccc}
\hline $\begin{array}{c}\text { Sample } \\
\text { Number }\end{array}$ & $\begin{array}{c}\text { Laboratory } \\
\text { Number }\end{array}$ & $\begin{array}{c}\text { Sampled Unit } \\
\text { (Fig. 6) }\end{array}$ & ${ }^{13} \mathrm{C} /{ }^{12} \mathrm{C}$ Ratio & $\begin{array}{c}{ }^{14} \mathrm{C} \text { Age } \\
\left({ }^{13} \mathrm{C} \text { corrected }\right) \text { B.P. }\end{array}$ & $\begin{array}{c}\text { Calibrated Age } \\
\text { A.D. }(2 \sigma)\end{array}$ \\
\hline $14 \mathrm{C}-1$ & Beta-135,199 & W2a & -25.9 & $490 \pm 40$ & $1395-1485$ \\
$14 \mathrm{C}-2$ & Beta-135,200 & L5 & -26.1 & $260 \pm 30$ & $1520-1570(14 \%)$ \\
& & & & & $1620-1680(61 \%)$ \\
& & & & & $1770-1810(17 \%)$ \\
$14 \mathrm{C}-3$ & Beta-135,201 & L5 & -29.4 & $190 \pm 40$ & $1660-1890$ \\
$14 \mathrm{C}-4$ & Beta-135,202 & L2 & -22.5 & $280 \pm 40$ & $1480-1680$ \\
$14 \mathrm{C}-5$ & Beta-135,203 & F4 & -26.6 & $1590 \pm 40$ & $400-600$ \\
\hline
\end{tabular}

All samples were pretreated with standard acid and base wash. Calib 3.0 software (Stuiver and Reimer, 1993) was used for calibration.

In trench 1 the fault zone is $10-20 \mathrm{~cm}$ wide. Sediments have been reoriented to align with the shear direction. At the base of the fault zone some pebbles are tilted toward the northeast, in good agreement with normal motion on the fault. Two small faults branch off the main fault zone and end in colluvial wedge W2a. This indicates that they formed after the formation of the wedge. Sediments (mapped in purple), trapped between those faults and the main fault zone, have been highly sheared and cannot be associated confidently to any of the units outside the fault zone.

The stratigraphy and structural relationships in trench 1 suggest the occurrence of at least two faulting events: colluvial wedge W1 resulted from the collapse of a scarp, later mantled by suspended-load units L2 and L3 and the formation of an organic soil on unit L3. It is worth noting that this soil is thinner and less mature than the soil exposed at the present ground surface. This difference might be due to the intense plowing of the present surface. Later, the scarp was refreshed by faulting and colluvial wedge W2 and units L4-L7 were deposited. Finally, following a new period of modest soil formation, faulting in 1999 once again refreshed the scarp.

The date of the faulting event that led to the formation of colluvial wedge W2 is constrained by three radiocarbon dates (Table 1). Two samples of detrital charcoal in unit L5 yielded AMS calibrated radiocarbon age ranges of A.D. 15201810, with the most probable date ranges being A.D. 1620 1680 and 1660-1890 (Table 1, samples 14C-2 and 14C-3). A third sample (Table 1, 14C-1), from the middle of wedge W2, yielded an accelerator mass spectrometry (AMS) calibrated radiocarbon age of A.D. 1395-1485. Based on the consistency of the other dates from the two trenches, this last date very probably is from a chunk of detrital charcoal that antedates the stratum. The three other dates provide a maximum limiting age for the faulting event, since detrital charcoal often antedates the age of the stratum in which it occurs (Nelson et $a l ., 2000)$. Thus, the youngest of the three dates, A.D. 1660 1890 , gives the closest maximum limiting date range for the faulting event that led to the formation of wedge W2.

Trench 2. Trench 2 was excavated about $15 \mathrm{~m}$ southeast of trench 1 to explore the relationship between the older, and deeper, units on the down-thrown side of the fault. The flooding that resulted from this attempt to expose older layers led to partial collapse of the walls of the trench, which thwarted our attempts to map a complete exposure of the wall. Instead, we had to map an inset into the main exposure separately from the principal exposure (Fig. 7). Also, the principal exposure had to be benched to prevent additional collapse.

Trench 2 exposed stratigraphic units similar to those in trench 1 . As in trench 1, only the uppermost soil occurs on both sides of the fault. The up-thrown block consists of beds of fine to coarse sandy cobble gravel, overlain by beds of coarse sand to silt. Grain size and distribution, erosional scours, and cross-bedding all indicate deposition on a braided riverbed. As in trench 1, the grain size and grading of the finer-grained units on the upper part of the up-thrown block are indicative of overbank deposition.

Detrital charcoal from a silty bed near the base of the oldest exposed sediment yielded an AMS calibrated radiocarbon age of A.D. 995-1162. This is about 500 years younger than the age of the detrital sample from the overlying beds in trench 1 . We suspect that this indicates that the sample from trench 1 is several hundred years older than the age of the enclosing stratum. The simplest interpretation of this discrepancy is that the A.D. 995-1162 age from trench 2 is a better estimate of the age of the coarse fluvial section in both trenches.

Despite the poor condition of the wall of trench 2 on the down-thrown block, we were able to map the relationships exposed. The exposure reveals the same two colluvial sequences that appeared in trench 1 . In addition, trench 2 provided a good exposure of the units underlying wedge $\mathrm{W} 1$ (Figs. 7 and 8) and allowed a better understanding of the basic relationship between the units and the fault zone. Unlike the exposure in trench 1 , however, the fault zone in trench 2 is complicated by warping of the down-thrown block adjacent to the fault.

Trench 2 more clearly exposes the fluvial deposits (G0) that were only partially exposed at the bottom of trench 1 (Figs. 7 and 8). This fluvial unit is dominated by a thick, massive pebble gravel lens. Thin silty sand beds (units P1P3) overlie and underlie the gravel away from the fault. The 


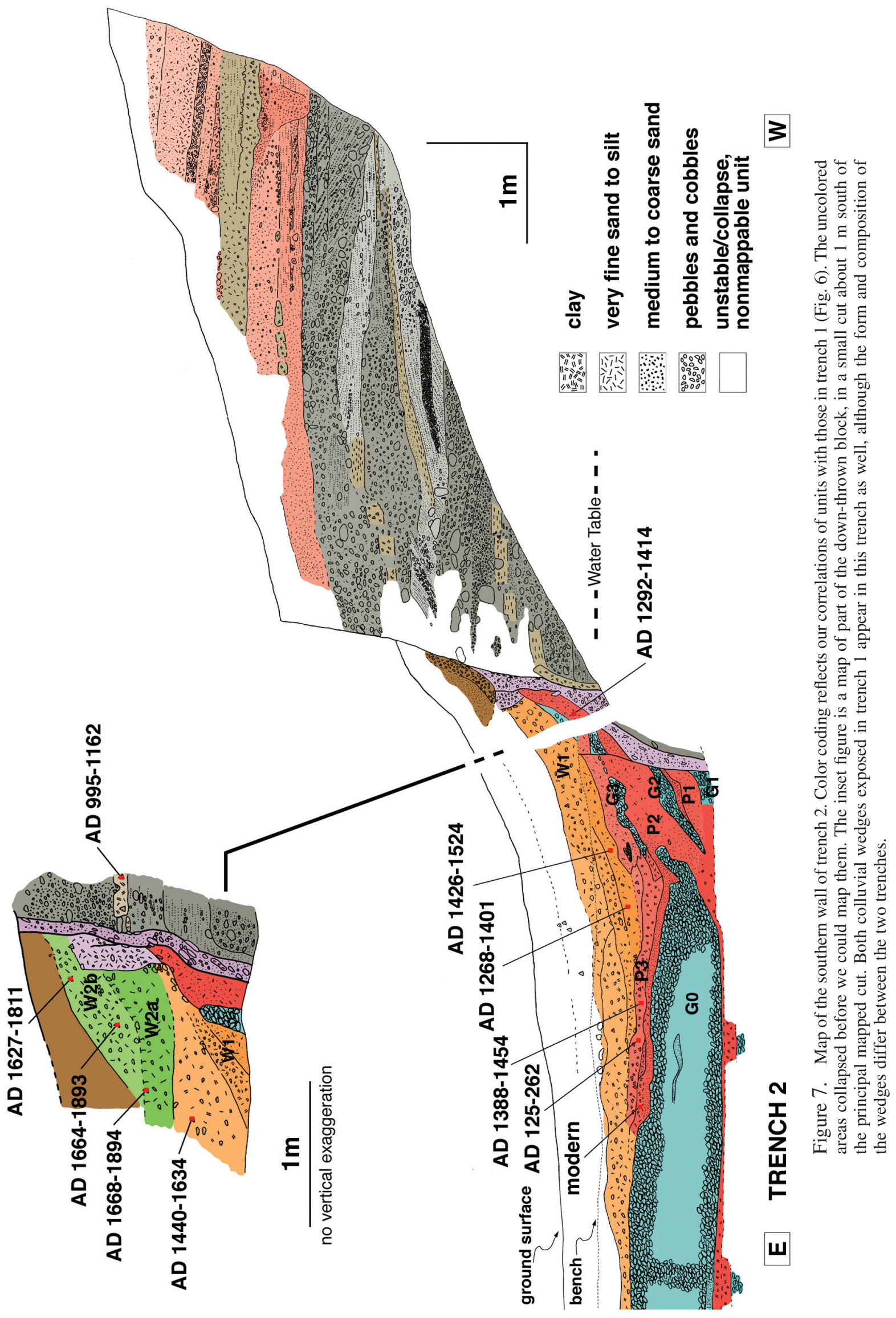



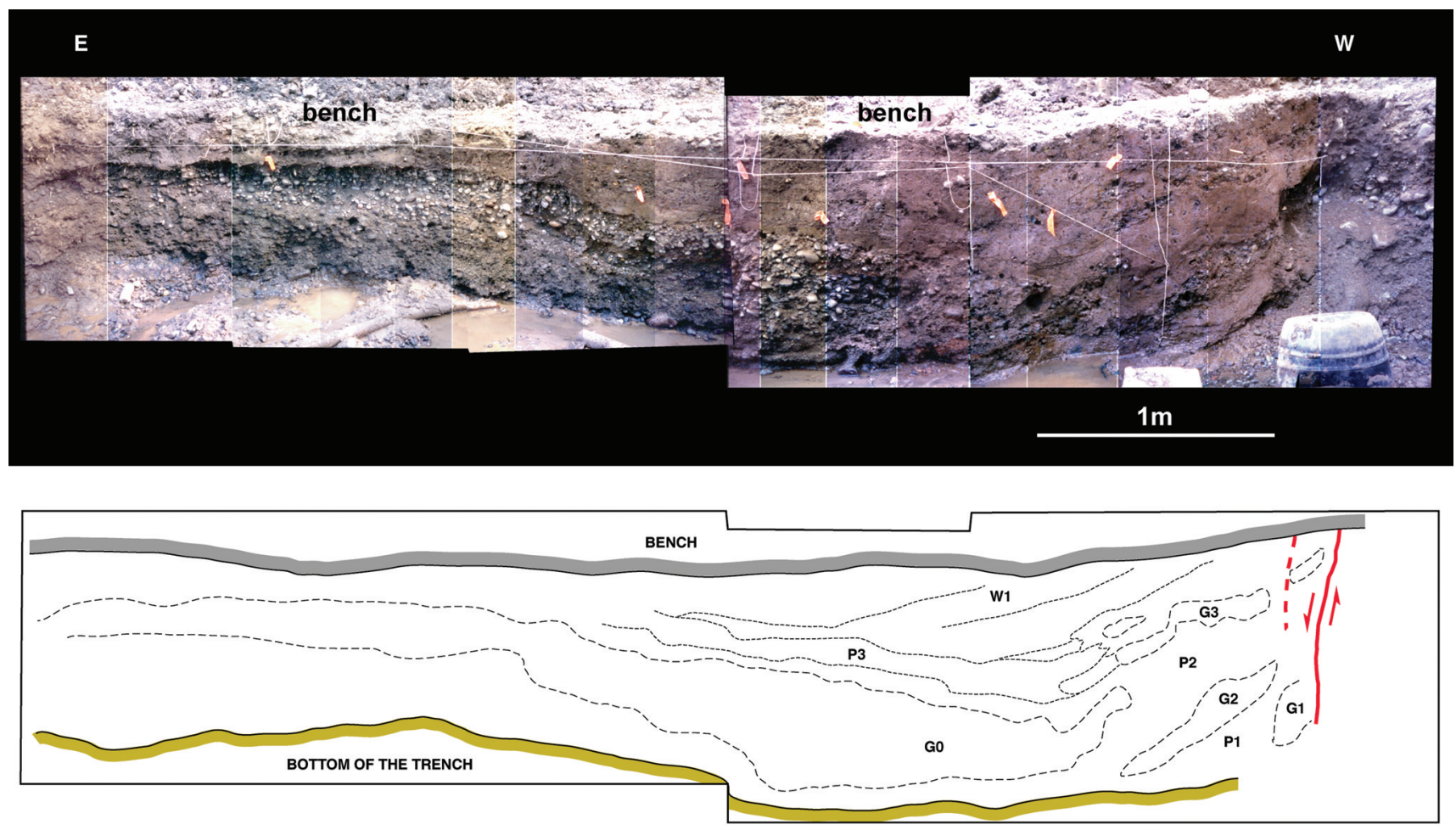

Figure 8. The upper panel shows a photo mosaic of the lowest exposed part of the down-thrown block in trench 2 . The fluvial gravel bed and its warping near the fault are clearly visible. The fine sandy and silty units that warp up along the fault and are intercalated with the coarse fluvial gravel are also clearly visible. The lower panel outlines the main units of the lower part of the trench 2, with labeling referring to Figure 7.

thick gravel bed G0 pinches out before intersecting the fault. It also pinches out about $12 \mathrm{~m}$ east of the fault, but this part of the trench is not shown in Figure 7. Within $1 \mathrm{~m}$ of the fault, the lower unit consists of several small lenses of pebble gravel, G1-G3, surrounded by fine sand to silt, P1-P3. The long axes of both the large and the small lenses are parallel to the trend of the fault scarp. This indicates that the gravel beds were deposited by a stream flowing parallel to and next to the scarp. Units P3 and below exhibit eastward tilt within $1 \mathrm{~m}$ of the fault zone (Fig. 7).

Detrital charcoal from near the top of the lowest unit yielded an AMS calibrated radiocarbon age of A.D. 12921414 (Table 2, For-14). This date range provides a maximum limiting age for the stratum. Note that this age range is at least a century or two younger than the maximum limiting age of the coarse gravels on the up-thrown side of the fault. This is consistent with redeposition of materials from the up-thrown block at the base of the fault scarp.

Colluvial wedge W1 caps the lowest unit (Fig. 7). As in trench 1, this wedge consists of poorly sorted silt, sand, and pebbles. The shape of the unit indicates that it was formed by deposition of materials eroded from the fault scarp. The shape of colluvial wedge W1 differs from that in trench 1 , because in trench 2 the portion of the wedge nearer the fault rests on tilted underlying sediment (top of unit P3).
Thus, the thickest part of the wedge is not at the fault but $1 \mathrm{~m}$ away.

Several samples of detrital charcoal constrain the age of this colluvial wedge. AMS radiocarbon ages of samples from this deposits range widely, from about the first century A.D. to the present (Table 2). The modern sample must represent a root that was interpreted in error to be detrital charcoal. The 2000-year-old sample must surely be a piece of charcoal that was eroded from an older stratum and redeposited twice, first in the fluvial units of the up-thrown block and then reeroded and deposited in the colluvial wedge. The remaining four AMS radiocarbon ages more closely approximate the time of deposition of the wedge. The three age ranges from strata near the bottom of the wedge are A.D. 1388-1454, 1268-1401, and 1426-1524 (Table 2; Fig. 7). The youngest of these, A.D. 1426-1524, provides a maximum limit to the age of the stratum, as it, too, could have been reworked from soil that rested on the up-thrown side of the fault. This suggests that the wedge began to form during or after the fifteenth century. The age range for a sample near the top of the wedge is A.D. 1440-1634. This is not appreciably younger than the age range for a sample at the base of the wedge. This age range is indistinguishable from the age range determined on charcoal from the younger part of the wedge in trench 1, A.D. 1480-1680 (Table 1, 14C-4). 
Table 2

Radiocarbon Dates for Trench 2

\begin{tabular}{lcccc}
\hline $\begin{array}{l}\text { Sample } \\
\text { Number }\end{array}$ & $\begin{array}{c}\text { Laboratory } \\
\text { Number }\end{array}$ & $\begin{array}{c}\text { Sampled Unit } \\
\text { (Fig. 7) }\end{array}$ & $\begin{array}{c}{ }^{14} \mathrm{C} \text { Age } \\
\left({ }^{13} \text { C corrected) B.P. }\right.\end{array}$ & $\begin{array}{c}\text { Calibrated Age } \\
\text { A.D. (2 } \sigma)\end{array}$ \\
\hline Gol-04 & CAMS-70739 & Up-thrown block & $970 \pm 40$ & $995-1162$ \\
For-14 & CAMS-70740 & P2 & $610 \pm 50$ & $1292-1414$ \\
Gol-15 & CAMS-70741 & P2 & Modern & Modern \\
Gol-01 & CAMS-70742 & P3 & $1810 \pm 40$ & $125-262$ \\
Gol-16 & CAMS-70743 & P3 & $510 \pm 40$ & $1388-1454$ \\
Gol-08 & CAMS-70744 & W1 & $670 \pm 50$ & $1268-1401$ \\
Gol-09 & CAMS-70745 & W1 & $410 \pm 40$ & $1426-1524$ \\
Gol-11 & CAMS-70746 & W1 & $380 \pm 40$ & $1440-1634$ \\
Gol-12 & CAMS-70747 & W2 & $140 \pm 40$ & $1668-1894$ \\
Gol-20 & CAMS-70748 & W2 & $150 \pm 50$ & $1664-1893$ \\
Gol-19 & CAMS-70749 & W2 & $230 \pm 40$ & $1627-1811$ \\
\hline
\end{tabular}

All samples where processed at the Lawrence Livermore National Laboratory AMS facility. Samples were pretreated with standard acid and base wash. $\delta^{13} \mathrm{C}$ is assumed to be -25 . Calib 4.3 software (Stuiver and Reimer, 1993) was used for calibration.

The upper colluvial wedge $\mathrm{W} 2$ in trench 2 is quite similar to the upper wedge exposed in trench 1 . Wall collapse prevented us from mapping this wedge as completely as we did in trench 1 . Nonetheless, we were able to clearly define the two units (W2a and W2b) that represent the initial collapse of the fault scarp. These units are composed mostly of unsorted silt and gravel. As in trench 1, the contact between $\mathrm{W} 2 \mathrm{a}$ and $\mathrm{W} 2 \mathrm{~b}$ is characterized by a darker color. This more organic horizon indicates a short period of soil formation prior to emplacement of the remainder of the wedge.

AMS radiocarbon ages from three detrital charcoal samples constrain the period of accumulation of colluvial wedge W2. These age ranges, A.D. 1668-1894, 1664-1893, and 1627-1811, (Table 2) are indistinguishable from one another and in agreement with the ages in trench 1 . They indicate that the wedge formed after about A.D. 1668.

As in trench 1, the fault zone is quite simple in trench 2. The main fault zone is about $20 \mathrm{~cm}$ wide, with many pebbles tilted by shear. Some of the fine units from the upthrown block have also been dragged into the fault zone, but identifying the original location of the dragged chunk would require more intensive dating of each fine unit of the upthrown block than we did. As in trench 1, one secondary fault branches off the main fault zone, cutting lower units P2 and P3. This minor fault appears to terminate upward in the bottom of unit W1.

\section{Summary of the Evidence for Paleoseismic Events}

Both trenches clearly expose the Gölcük fault, directly below the scarp that formed in 1999. In trench 1 it is a 10to 20 -cm-wide zone of normal faulting that dips $70^{\circ}$ northeastward. In trench 2 the fault consists of both a discrete, narrow fault plane and a meter-wide zone of warping just northeast of the fault. Both exposures reveal two colluvial wedges on the down-thrown block at the foot of the fault scarp. The youngest wedge, W2, is of similar size and form in the two exposures. Trench 1 exposed the late-stage deposits that form the upper, more distal part of the wedge. In both trenches a dark organic soil developed on the top of the lower unit W2a. This suggests that a short period of time separated the formation of the lower and upper portions of the wedge. AMS calibrated radiocarbon dates, which represent maximum ages for the deposition of wedge W2, are consistent between the two trenches (Table 1 and 2) and indicate that the wedge formed sometime after about A.D. 1660.

In trench 1 two small faults that splay off of the main fault plane disrupt the base of colluvial wedge 2 . These faults might be associated with the formation of the upper part of the wedge 2 (W2b) separated from the lower part of the wedge (W2a) by the weak organic soil. In that case these small faults suggest that wedge 2 might represent two events. These secondary faults, however, may also have been caused by the 1999 earthquake.

Both excavations expose an earlier colluvial wedge, W1. In trench 1, the oldest part of wedge W1a is a block of debris that fell intact from the scarp. Another short prism of debris, W1b, overlies it. Between these two initial collapse deposits and the upper colluvial deposits of the wedge is a suspended-load bed, L1. The stratigraphy of the wedge exposed in trench 2 is consistent in general with that in trench 1 , but it is also complicated by additional warping. The unstable nature of trench 2 , however, obscured much of the stratigraphic relationships. The radiocarbon ages from samples within wedge $\mathrm{W} 1$ indicate that it formed sometime during or after the period A.D. 1426-1524 (Tables 1 and 2).

The near-fault warping of the layers beneath wedge W1 is not evidence for a still-earlier episode of deformation. This warping appears to be quite localized, since we do not see it in trench 1. Some warping may also have occurred in trench 1 that has not been exposed, but in any case it would be smaller. Nonetheless, the warping is quite useful, because it is independent evidence for the faulting that led to depo- 
sition of wedge W1. If a fold or fault scarp formed in association with this warping, we would expect the concomitant deposition of debris eroded from the scarp directly atop the warped beds. Since wedge 1 lies directly upon the warped beds, that wedge is the result of faulting that accompanied the warping.

\section{Offsets during the Paleoearthquakes}

We have documented evidence for three scarp-forming episodes at this site along the Gölcük fault. The earliest led to the formation of wedge 1 . The second resulted in the formation of wedge 2. And the most recent was associated with the $M_{\mathrm{w}} 7.4$ Izmit earthquake of August 1999. The height of the scarp associated with the 1999 event is $1.6 \mathrm{~m}$ at trench 1 and $1.1 \mathrm{~m}$ at trench 2 . The height of the scarps associated with the earlier events must be inferred from the height of the two buried wedges and the cumulative height of the fault scarp.

In estimating the offset of the two paleoseismic scarps, an evaluation of the cumulative scarp offset is a good place to start. From the extrapolation of slopes on both sides of the fault, the apparent cumulative scarp is about $3.8 \mathrm{~m}$ high (Fig. 5b). If we subtract the $1.6 \mathrm{~m}$ of vertical slip that occurred at trench 1 in 1999, we estimate that the total offset that produced the pre-1999 scarp was about $2.2 \mathrm{~m}$. If the surfaces on both sides of the fault scarp were the same age, we would conclude that this is the amount of offset across the fault since the date of formation of the disarticulated surface. In this case, however, the two surfaces are not correlative. The up-thrown surface is the top of the sandy overbank deposits that must have been deposited after about A.D. 1000 (sample Gol-4, trench 2). The down-thrown surface is approximately the top of the sand and gravel sequence that underlies wedge 1 . Its age must be younger than the age of the youngest beds on the up-thrown block, that is, an age between about A.D. 1000 and the age of wedge 1, perhaps A.D. 1500 .

Another complication in using the cumulative scarp height to estimate the magnitude of earlier offsets is the fact that the up-thrown block next to the fault has been modified by agricultural activities and road building. The best we can do with the cumulative scarp height is to say this: since deposition of the lower gravel and sand unit on the downthrown block, the vertical offset has been at least $2.2 \mathrm{~m}$ in addition to the $1.6 \mathrm{~m}$ that accumulated in 1999 .

The shape and size of the two colluvial wedges at the base of the fault scarp are far more useful in determining the offsets associated with the two prior episodes of scarp formation. Since Wallace's (1977) seminal paper on the nature of fault scarps in granular materials, many have investigated colluvial wedges that form at the base of fault scarps. Many paleoseismic studies of normal faults have used the presence of eroded scarp debris as evidence for paleoearthquakes (e.g., Schwartz and Coppersmith, 1984; Schwartz and Crone, 1985; McCalpin and Nishenko, 1996). Others have used physical models based upon diffusion equations to understand the processes of erosion and deposition that follow the formation of a fault scarp (e.g., Nash, 1980; Avouac and Peltzer, 1993; Hanks, 2000). Observations demonstrate that once a scarp has been created, the first stage in the process of modification involves gravity-induced collapse. The length of this period depends upon the cohesion of the faulted material, the regional slope, and the climatic conditions (Arrowsmith and Rhodes, 1994). Diffusive processes predominate later. These are controlled by the erosion of material from the upper half of the scarp and deposition downslope. This process tends to smooth the profile across the former fault scarp. Typically, if the regional slope is not too steep, the steady state is achieved when the elevation of the inflection point between the convex (up-thrown block) and the concave (down-thrown block) part of the slope reaches about half of the total height of the initial free scarp (Fig. 9).

(a)

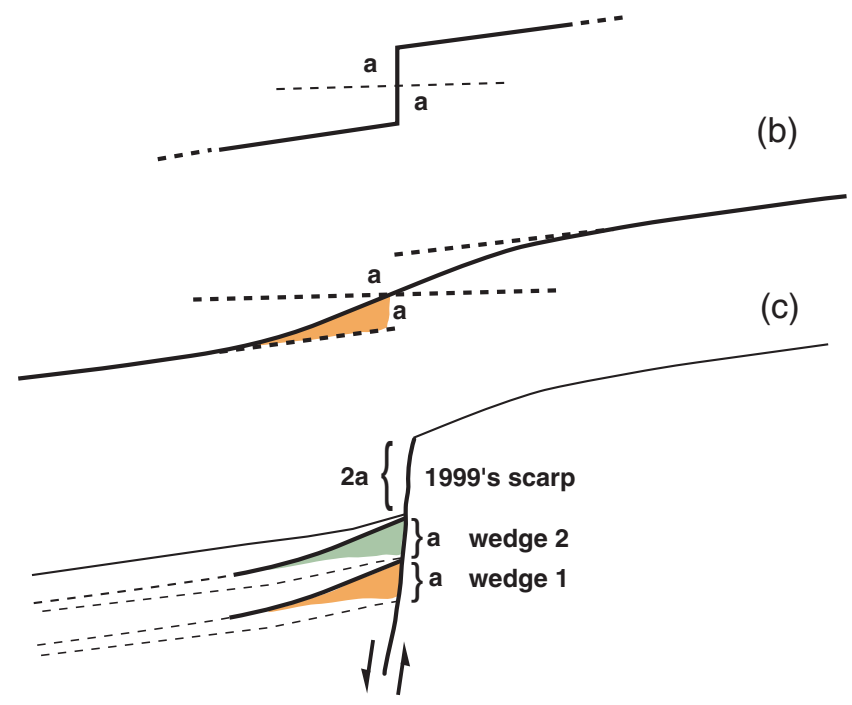

Figure 9. An idealized representation of the formation of the scarp and colluvial wedges during three successive ruptures. The height of the scarp formed during both earthquakes equals twice the thickness, $a$, of the colluvial wedge that forms subsequently on the downthrown block. (a) First sudden dislocation of the fluvial surface results in a scarp of height $2 a$. (b) After the first dislocation, the scarp degrades to form a colluvial wedge of thickness, $a$. In this idealization, the volume of material eroded from the scarp equals the volume of material emplaced at the toe of the scarp. The dislocation and erosion depicted in (a) and (b) repeat one more time before the dislocation of 1999. (c) The configuration of scarp and colluvial wedges at the Gölcük trench site immediately following the 1999 rupture. The 1999 scarp has a height of $2 a(1.6 \mathrm{~m})$ and the height, $a$, of each colluvial wedge is about 0.8. The fact that the 1999 scarp is about twice as high as the colluvial wedges are thick suggests that the past three ruptures have been of the same magnitude, about $1.6 \mathrm{~m}$. 
In the case of a normal fault, the colluvial wedge underlies the concave-upward, lower half of the slope, which is buried during the formation of the colluvial wedge related to the next earthquake. The height of the colluvial wedge should therefore give us a net indication of the local size of the coseismic slip.

In trench 1, if we extend the base of wedge $\mathrm{W} 1$ to the scarp, assuming no dramatic geometric change in the unexposed part of the wedge, the thickness of W1 at the fault is $0.8 \pm 0.3 \mathrm{~m}$ (Fig. 6). Later faulting of colluvial wedge 1 obscures this measurement somewhat, which leads to the large error indicated. The thickness of colluvial wedge 2, also measured at the fault in trench 1 , is $0.7 \pm 0.1 \mathrm{~m}$ (Fig. 6) if we consider only W2a and $0.9 \pm 0.1 \mathrm{~m}$ if we consider the entire wedge, W2.

The restoration of the surfaces through the earthquake series (Fig. 10) shows the relation between the height of individual wedges and the total fault offset during each earthquake, assuming the model discussed previously (Fig. 9). It is obvious from this reconstruction that the units from the downstream block could not originate from the unit we have exposed in the up-thrown block.

The height of the two colluvial wedges W1 and W2 are quite similar; in fact they are indistinguishable. The height of the 1999 scarp at the trench location is $1.6 \pm 0.1 \mathrm{~m}$ (Fig. $5 \mathrm{~b}$ ), about twice the height of the older colluvial wedges. This suggests that the scarps associated with the paleoseismic colluvial wedges 1 and 2 were similar in size to the fault scarp created in 1999. This would mean that at this location slip during the past three episodes has been identical, or nearly so. This similarity supports the hypothesis that faults tend to produce offsets of similar size during serial ruptures.

\section{Insights from Historical Accounts}

Written history for the region surrounding the Sea of Marmara extends more than two millennia into the past. This is because Istanbul (formerly Constantinople) has long been a center of trade and political activity. Several earthquake catalogs have been compiled for the region. Ambraseys and Finkel (1995) and Ambraseys (2002) have provided the most recent review of these records. Because radiocarbon analyses constrain the fault ruptures we have identified in our excavations to the historical period, we may well be able to assign specific dates to these events. The oldest episode of rupture exposed in the excavations occurred sometime after about A.D. 1425. The second episode occurred sometime after about A.D. 1660, and it may represent two distinct events. According to Ambraseys and Finkel (1991, 1995), no large destructive earthquakes occurred in the region between an event on 25 October 989 and the great Marmara earthquake of 10 September 1509. Thus the oldest date we could assign to our oldest event is A.D. 1509. The next large earthquake after this is the destructive earthquake of 25 May 1719. This is also the first large event after the maximum limiting age for the second wedge, A.D. 1660. Thus 1509 and 1719 are good candidates for the events that resulted in the formation of wedges 1 and 2 .

However, several other large events occurred later in the eighteenth century: one in A.D. 1754 and two in 1766. An additional large event occurred in the region in 1894. Thus our second episode of faulting can plausibly be associated with any of these five earthquakes.

The 1509 earthquake was felt throughout the eastern Mediterranean basin, as far as the Nile delta, and caused heavy damage around the Sea of Marmara. Istanbul was severely damaged. It is reported that this earthquake was responsible for the death of 4000-5000 people (Ambraseys and Finkel, 1990). Since there are no reports of faulting during the event, the lateral extent of the rupture is largely a matter of speculation. Based upon interpretation of the levels of shaking experienced at various locations, Ambraseys and Jackson (2000), Ambraseys (2001), and Parsons et al. (2000) considered whether or not this earthquake involved rupture of the fault throughout the entire length of the Sea of Marmara and beyond. The historical data are not sufficient for resolving this issue; most of the reported damage occurred west of Istanbul, but some eastern cities, including Izmit, were also severely damaged (Ambraseys and Finkel, 1995). Our data suggest that the Golcük segment did break during the 1509 earthquake, and the dislocation at our site was of the same sense and magnitude as that in 1999.

Assigning a precise date to the second event identified in the trenches is more difficult. The AMS radiocarbon dates indicate that this earthquake occurred after about A.D. 1660. Five large earthquakes occurred between that date and 1999. The two large events in 1766 have intensity patterns that limit their source ruptures to the Sea of Marmara and the Gelibolu peninsula, well west of our site. But felt reports (Ambraseys and Finkel, 1995) for the events of A.D. 1719, 1754, and 1894 indicate severe damage in the region of Izmit.

The earthquake of 25 May 1719 destroyed most of the towns on the coasts of the Bay of Izmit, from Yalova, $64 \mathrm{~km}$ west of our excavations, to Düzce, $100 \mathrm{~km}$ to the east (Ambraseys and Finkel, 1991). The number of casualties in this event may have been as large as 6000 .

The earthquake of 2 September 1754 also destroyed many villages around the Bay of Izmit, but the city of Izmit itself is not specifically mentioned as having been severely damaged. So it may be, as proposed by Ambraseys (2002), that the earthquake was not produced by rupture of any faults close to the town of Izmit but further west in the gulf, or even in the Sea of Marmara. The magnitude of this earthquake appears from the extent and severity of the felt reports to have been smaller than the magnitude of either the 1719 or 1894 earthquakes (Ambraseys and Finkel, 1995).

The earthquake of 10 July 1894 strongly affected the region of Izmit and the southwestern coastline of the Gulf of Izmit. Some ground failures also occurred east of Izmit, in the area of the Lake Sapanca. Ambraseys's (2002) reassessment of the distribution of the destruction places this 


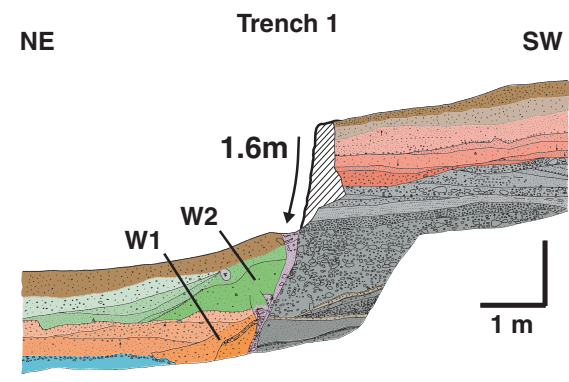

a) After the 1999 earthquake

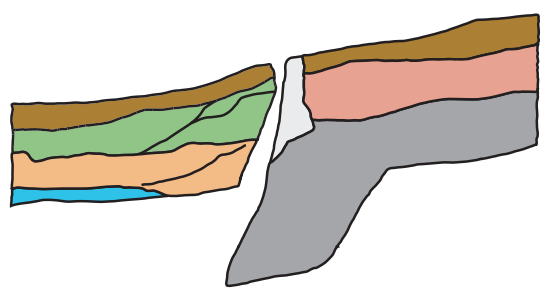

b) Just before the 1999 earthquake

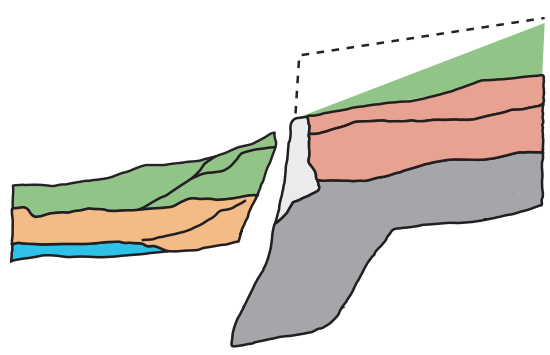

c) Emplacement of wedge W2

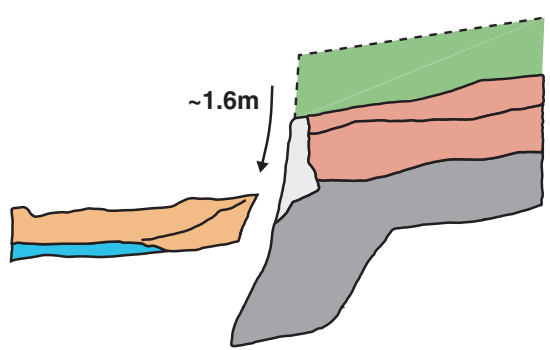

d) Just after the penultimate earthquake

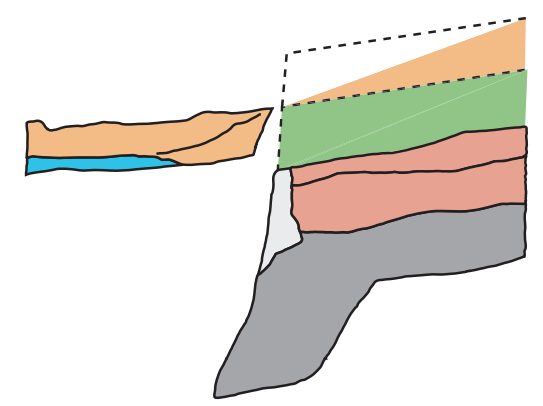

e) Emplacement of wedge W1

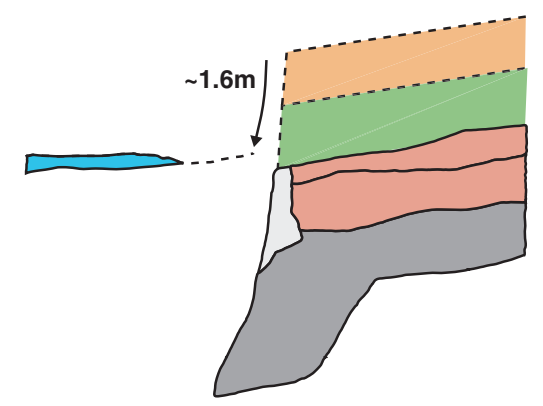

f) Just after the oldest earthquake we have identified in trench 1

Figure 10. Possible restoration of trench 1 following the model described in Figure 9. (a) The present situation. (b) Restoration of the ground surface to its position prior to the 1999 event. The trench log has been simplified for more clarity. (c) Restoration of the scarp when the diffusive processes have reached a state of equilibrium. Some bed-load lenses have draped the toe of the wedge at its northeast end. The soil at the present ground surface does not exist yet. (d) The penultimate earthquake has just happened. Wedge W2 does not exist yet and the fault scarp is about $1.6 \mathrm{~m}$ high. (e) Formation of wedge W1 from the oldest earthquake we can identify in trench 1, similar to (c). (f) Geometry of the different units when the oldest event has just happened. W1 has not formed yet.

event on the southern coast of the Gulf of Izmit. However, the intensities derived from the description of the damage seem generally lower than the intensities derived for the same places during the 1719 event (Parsons et al., 2000) or the 1999 event (USGS, 2000). Therefore we can assume that this event was smaller in size than the 1719 and 1999 earthquakes.

From this set of observations, we suggest that the sec- ond event we have identified in the trenches is associated with the earthquake of 25 May 1719. Ambraseys and Jackson (2000) have estimated a magnitude of $M_{\mathrm{s}} 7.4$ for this event, identical to the magnitude of the 1999 earthquake. Moreover, our interpretation is in good agreement with Parsons et al. (2000), who assigned historical events to fault segments using a probabilistic method (Bakun and Wentworth, 1997) applied to the macroseismic data. In their anal- 
ysis of the felt reports of the 1509, 1719, 1754, and 1894 events, only the 1719 earthquake involved rupture of the Golcük segment for both minimal and maximal rupture scenarios.

\section{Discussion}

The 17 August 1999 earthquake rupture along the North Anatolian fault provides a rare opportunity to study the repeatability of fault displacement at a specific location through several earthquakes. We have selected a site along the Gölcük fault where the fault trace is unusually simple and shows a topographic scarp height about twice the height of the 1999 scarp.

The two trenches we have opened show consistent stratigraphy with clear evidence for two previous earthquakes. The oldest earthquake, event 1 , can be clearly identified from the lowest colluvial wedge, $\mathrm{W} 1$, which is nicely exposed in the two trenches. Radiocarbon dates and historical accounts are consistent with this rupture being associated with the great earthquake of 1509 .

The upper wedge, W2, is also clearly expressed, and radiocarbon dates and historical records suggest that it formed at the base of a scarp associated with the 1719 earthquake. However, the presence of a weak soil within this wedge and the occurrence of lesser earthquakes in the region in 1754 and 1894 give credence to the possibility that this wedge is a composite of more than one event. Since only a weak soil formed atop the collapse debris before deposition of the wash debris, we might doubt a multiple-event origin for this second wedge. Nonetheless, the presence of two small secondary faults within the lower part of the second wedge suggests independently the composite nature of the second wedge. Hence, we favor the interpretation that the second wedge formed in association with both the 1719 and 1894 earthquakes. This is supported by recent analyses of the historical catalogs (Ambraseys, 2000; Ambraseys and Jackson, 2000). We cannot exclude the possibility that minor rupture of the base of wedge 2 also occurred during the 1754 earthquake. However, the relatively small intensities at Izmit in 1754 and 1894 argue against this.

Figure 11 displays the history of vertical offset at the site, assuming that we have interpreted the two paleoseismic colluvial wedges correctly. Between 989 and 1509, the historical record (Ambraseys, 2002) suggests that the fault was quiescent, although we have no data from the site to either confirm or deny this. In 1509, an offset about double the thickness of wedge 1 (about $1.6 \mathrm{~m}$ ) occurred. The offset of 1719 , quite possibly in combination with offsets in 1754 or 1894, was about twice the height of wedge 2 (also about $1.6 \mathrm{~m}$ ). And, most recently, the 1999 event added another $1.6 \mathrm{~m}$ to the height of the scarp.

Although some uncertainties remain, this history of three serial ruptures suggests a tendency toward both similar magnitude of offset at a site and nearly periodic rupture. However, the possible involvement of two increments of

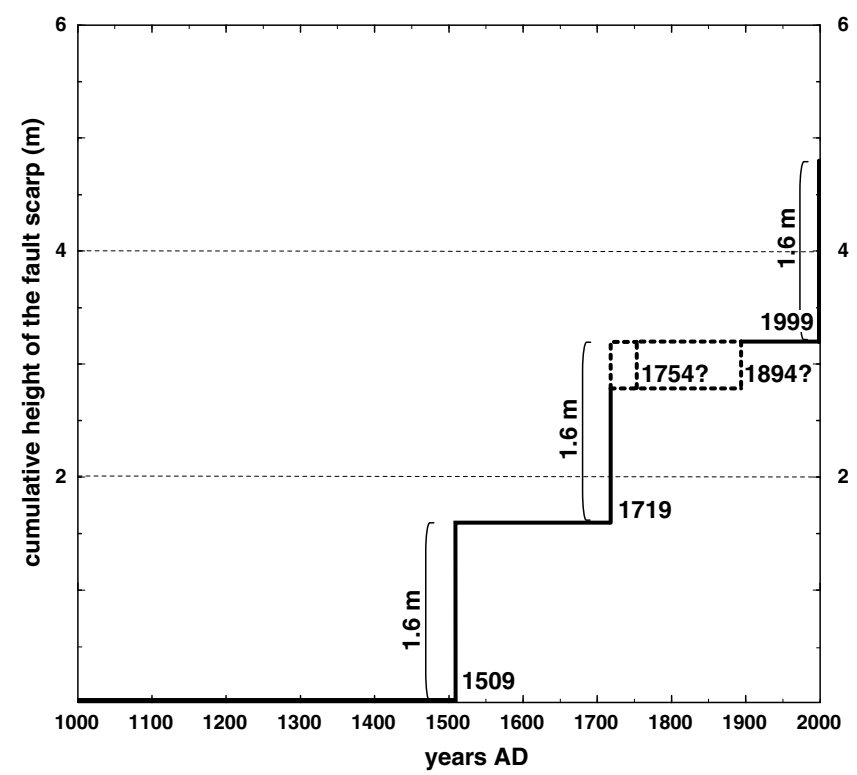

Figure 11. Tentative vertical offset across the fault through time from paleoseismic and historical data, following the assumption that the height of the colluvial wedge is indicative of the total height of the coseismic scarp. The 1509 and 1999 earthquakes have a very similar displacement. The dashed lines illustrate different scenarios for the middle event that conform with the data associated with the formation of wedge 2 . Either only one large earthquake with an offset of $1.6 \mathrm{~m}$ occurred in 1719 , or two smaller earthquakes occurred in 1719 and 1754 or 1894 . The possibility of having three earthquakes seems very unlikely from the trench exposure.

faulting in the eighteenth century (1719 and 1754) or another in 1894 creates significant ambiguity. And the apparent fivecentury hiatus in activity during the first half of the millennium also argues that any short-term periodicity does not hold for the long term. A hitherto unrecognized earthquake in the middle of the thirteenth century would erase this irregularity quite effectively, but the historical record appears to be complete for the first half of the millennium (Ambraseys, 2002).

This study of a single paleoseismic site does not answer all of the current questions about the nature of serial rupture of active faults. For example, we still do not know how the lengths of the 1509, 1719, and 1999 ruptures compare. Different interpretations of macroseismic data (Ambraseys and Finkel, 1995; Ambraseys and Jackson, 2000; Parsons et al., 2000; Ambraseys, 2002) and paleoseismological data (Rockwell et al., 2001) do not agree, but do show that rupture lengths were not similar for these events. Thus, we can reject the characteristic-earthquake hypothesis (Schwartz and Coppersmith, 1984) in this case. If the eighteenthcentury event in our sequence is only one event, then a slippatch model (Sieh, 1996) may work. In this concept, the displacement is similar for each slip patch from event to event, although the number of adjacent slip patches that fail 
in each event may vary. This number could vary from one earthquake to the other, producing earthquakes of different magnitude. But if the eighteenth-century scarp formed during both the 1719 and 1754 or 1894 earthquakes, then even this hypothesis would be deficient.

Despite its limitations, this site along the 1999 North Anatolian rupture contributes significant data to an important debate about the repetition of fault rupture.

\section{Acknowledgments}

The authors wish to thank the Ford Otosan for its support during this work. Some of the maps have been prepared using the Generic Mapping Tool free software. We thank R. Langridge and D. Ragona for their help during the field work. J. Liu, R. Armijo, and B. Meyer helped to improve this manuscript by their comments. We thank M. Meghraoui and an anonymous reviewer for very helpful reviews that significantly improved our analysis of the data. In memoriam of A. Barka, who died tragically while the article was in review. This is Caltech Contribution Number 8989 and IPGP Contribution Number 1936.

\section{References}

Ambraseys, N. N. (2001). The earthquake of 1509 in the Sea of Marmara, Turkey, revisited, Bull. Seism. Soc. Am. 91, 1397-1416.

Ambraseys, N. N. (2002). The seismic activity of the Marmara Sea region over the last 2000 years, Bull. Seism. Soc. Am. 92, 1-18.

Ambraseys, N. N., and C. F. Finkel (1990). The Marmara Sea earthquake of 1509, Terra Nova 2, 167-174.

Ambraseys, N. N., and C. F. Finkel (1991). Long-term seismicity of Istanbul and of the Marmara Sea region, Terra Nova 3, 527-539.

Ambraseys, N. N., and C. F. Finkel (1995). The seismicity of Turkey and adjacent areas, a historical review, 1500-1800, Eren, Istanbul.

Ambraseys, N. N., and J. A. Jackson (2000). Seismicity of the Sea of Marmara (Turkey) since 1500, Geophys. J. Int. 141, F1-F6.

Armijo, R., B. Meyer, A. Barka, J. B. De Chabalier, and A. Hubert-Ferrari (2000). The fault breaks of the 1999 earthquakes in Turkey and the tectonics evolution of the sea of Marmara: a summary, in The 1999 Izmit and Ducze Earthquakes: Preliminary Results, A. Barka, O. Kozaci, S. Akayuz, and E. Altunel (Editors), Istanbul Technical University, Istanbul.

Armijo, R., B. Meyer, A. Hubert, and A. Barka (1999). Westward propagation of the North Anatolian fault into the northern Aegean: timing and kinematics, Geology 27, no. 3, 267-270.

Arrowsmith, J. R., and D. D. Rhodes (1994). Original forms and initial modifications of the Galway Lake road scarp formed along the Emerson fault during the 28 June 1992 Landers, California, earthquake, Bull. Seism. Soc. Am. 84, no. 3, 511-527.

Avouac, J.-P., and G. Peltzer (1993). Active tectonics in southern Zinjiang, China: analysis of terrace riser and normal fault scarp degradation along the Hotan-Qira fault system, J. Geophys. Res. 98, no. B12, 773807.

Bakun, W. H., and C. M. Wentworth (1997). Estimating earthquake location and magnitude from seismic intensity data, Bull. Seism. Soc. Am. 87, no. 6, 1502-1521.

Barka, A. (1992). The North Anatolian fault zone, Ann. Tectonicae 6, 164195.

Barka, A. (1996). Slip distribution along the North Anatolian fault associated with the large earthquakes of the period 1939 to 1967, Bull. Seism. Soc. Am. 86, 1238-1254.

Barka A. (1999). The 17 August 1999 Izmit earthquake, Science 285, 18581859.

Barka, A., S. Akyuz, E. Altunel, G. Sunal, Z. Cakir, A. Dikbas, B. Yerli, R. Armijo, B. Meyer, J. B. Chabalier, T. Rockwell, J. Dolan, R. Hartleb, T. Dawson, S. Christofferson, A. Tucker, T. Fumal, R. Lan- gridge, H. Stenner, W. Lettis, W. Page, and J. Bachhuber (2002). The surface rupture and slip distribution of the 17 August 1999 Izmit earthquake (M 7.4), North Anatolian fault, Bull. Seism. Soc. Am. 92, 43-60.

Gonzalez, T., K. Sieh, T. Dawson, E. Altunel, and A. Barka (2000). Faulting and ground subsidence at the Ford-Otosan Plant near Gölcük, Turkey as a result of the August 17, 1999 Kocaeli earthquake, Am. Assoc. Petrol. Geol. Bull. 84, no. 6, 870.

Hanks, T. C. (2000). The age of scarplike landforms from diffusionequation analysis, in Quartenary Geochronology: Methods and Applications J. S. Nollet, J. M. Sower, and W. R. Lettis (Editors), AGU, Washington, D.C.

Langridge, R. M., H. D. Stenner, T. Fumal, S. Christofferson, T. Rockwell, R. Hartleb, J. Bachhuber, and A. Barka (2002). Geometry, slip distribution, and kinematics of surface rupture on the Sakarya fault segment during the 17 August 1999 Izmit, Turkey earthquake, Bull. Seism. Soc. Am. 92, 107-125.

Lettis, W., J. Bachhuber, A. Barka, R. Witter, and C. Brankman (2000). Surface fault rupture and segmentation during the Kocaeli earthquake, in The 1999 Izmit and Ducze Earthquakes: Preliminary Results, A. Barka, O. Kozaci, S. Akayuz, and E. Altunel (Editors), Istanbul Technical University, Istanbul.

McCalpin, J., and S. Nishenko (1996). Holocene paleoseismicity, temporal clustering, and probabilities of future large $(M>7)$ earthquakes on the Wasatch fault zone, Utah, J. Geophys. Res. 101, 6233-6253.

McClusky, S., S. Balassanian, A. Barka, C. Demir, S. Ergintav, I. Georgiev, O. Gurkan, M. Hamburger, K. Hurst, H. Kahle, K. Kastens, G. Kekelidze, R. King, V. Kotzev, O. Lenk, S. Mahmoud, A. Mishin, M. Nadariya, A. Ouzounis, D. Paradissis, Y. Peter, M. Prilepin, R. Reilinger, I. Sanli, H. Seeger, A. Tealeb, M. N. Toksoz, and G. Veis (2000). Global positioning system constraints on plate kinematics and dynamics in the eastern Mediterranean and Caucasus, J. Geophys. Res. 105, no. 3, 5695-5719.

Nash, D. B. (1980). Morphologic dating of degraded normal fault scarps, J. Geol. 88, 353-360.

Nelson, A. R., S. F. Personius, R. E. Rimando, R. S. Punongbayan, N. Tungol, H. Mirabueno, and A. Rasdas (2000). Multiple large earthquakes in the past 1500 years on a fault in metropolitan Manila, the Philippines, Bull. Seism. Soc. Am. 90, no. 1, 73-85.

Parsons, T., S. Toda, R. Stein, A. Barka, and J. H. Dieterich (2000). Heightened odds of large earthquakes near Istanbul: an interaction-based probability calculation, Science $\mathbf{2 8 8 , 6 6 1 - 6 6 5 . ~}$

Rockwell T., A. Barka, T. Dawson, S. Akyuz, and K. Thorup (2001). Paleoseismology of the Gazikoy-Saros segment of the North Anatolia fault, northwestern Turkey: comparaison of the historical and paleoseismic records, implications of regional seismic hazard, and models of earthquake recurrence, J. Seism. 5, 433-448.

Schwartz, D. P., and K. J. Coppersmith (1984). Fault behavior and characteristic earthquakes: examples from the Wasatch and San Andreas fault zones, J. Geophys. Res. 89, 5681-5698.

Schwartz, D., and A. Crone (1985). The 1983 Borah Peak earthquake: a calibration event for quantifying earthquake reccurence and fault behavior on Great Basin normal faults, U.S. Geol. Surv. Open-File Rept. 85-290, 153-160.

Sieh, K. (1996). The repetition of large-earthquake ruptures, Proc. Natl. Acad. Sci. 93, 3764-3771.

Stein, R., A. Barka, and J. Dieterich (1997). Progressive failure on the North Anatolian fault since 1939 by earthquake stress triggering, Geophys. J. Int. 128, 594-604.

Stuiver, M., and P. J. Reimer (1993). Extended ${ }^{14} \mathrm{C}$ data base and revised CALIB $3.0{ }^{14} \mathrm{C}$ age calibration program, Radiocarbon 35 , no. 1, 215230.

Toksöz, M. N. (Editor) (2002). Issue dedicated to the Izmit, Turkey, earthquake of 17 August 1999, Bull. Seism. Soc. Am. 92, 526 pp.

U.S. Geological Survey (USGS) (2000). Implication for earthquake risk reduction in the United States from the Kocaeli, Turkey, earthquake of August 17, 1999, U.S. Geol. Surv. Circ. 1193. 
Wallace, R. E. (1977). Profiles and ages of young fault scarps, north-central Nevada, Geol. Soc. Am. Bull. 88, 1267-1281.

Walls, C., K. Sieh, Y. Klinger, A. Barka, S. Akyuz, and E. Altunel (2001). Geomorphology, paleoseismology, and effects of the $M 7.4$ August 17, 1999 Izmit earthquake on auxiliary strands of the Yalova fault (abstract). Presented at European Union Geosciences 11, 8-12 April, Strasbourg, France, 293.

Seismolab

California Institute of Technology

Pasadena, California 91125

(Y.K., K.S.)

Osmangazi University

Bademlik-Eskesehir, Turkey

(E.A.)
Istanbul Technical University

Istanbul, Turkey

(A.A., A.B.)

U.S. Geological Survey

Menlo Park, California 94025

(T.D.)

Earth Consultant International

Orange, California 92867

(T.G.)

San Diego State University

San Diego, California 92182

(A.M., T.R.)

Manuscript received 23 October 2001. 